\title{
Ground control methods in squeezing and rockburst-prone ground in mining - case studies and benchmarking
}

\author{
RM Stephenson AMC Consultants Pty Ltd, Australia \\ MP Sandy AMC Consultants Pty Ltd, Australia
}

\begin{abstract}
Underground mines with high rock stress to rock strength ratios tend to experience squeezing ground conditions or rockbursting conditions, or a combination of both. The ground control methods and strategies that have evolved to manage such conditions have some similarities and some differences. Mining can continue successfully in such adverse conditions provided appropriate ground control methods are applied.

This paper discusses various aspects of ground control in high stress environments and presents a literature review to discuss (1) the rock mass response to high stress conditions, and (2) the implications for ground support requirements and the effectiveness of support systems over the service life of development.

Case studies are presented to describe examples of ground control methods in both squeezing and rockburst-prone ground conditions. Information describing the current practices for ground control at a number of high stress underground mines is also presented.
\end{abstract}

Keywords: ground control, high stress, squeezing, rockburst-prone

\section{Introduction}

Underground mines with high rock stress to rock strength ratios tend to experience squeezing ground conditions or rockbursting conditions, or both. The ground control methods and strategies that have evolved to manage such conditions have some similarities and some differences. Mining can continue successfully in such adverse conditions provided appropriate ground control methods are applied.

An extensive study has been conducted on the rock mass response to high stress conditions. An overview of some of the key references in this area is presented in Section 2.

Once the rock mass conditions and the expected stress environment have been assessed the ground support requirements need to be considered. This includes the effectiveness of the support systems over the service life of the development. Multiple passes of rehabilitation will be required in most cases.

The ground control methods, including ground support requirements, will have implications for mine design and operating costs. Careful consideration should be given to the mining method, stoping sequence, rate of extraction, and infrastructure standoff distances. These should be determined using appropriate numerical modelling methods.

Case studies are presented to describe the ground control methods employed at two mines with squeezing ground conditions and rockburst-prone ground conditions. Ground support and rehabilitation requirements, monitoring requirements, and geotechnical input to mine design are discussed.

To provide broader context to the example mines discussed in the paper, benchmarking information documenting the ground support systems employed at a number of mines globally is presented in Section 5. 


\section{Determining rock mass response to high stress conditions}

Reports of mining-related seismicity and its association with elevated stresses date back more than a century. Moore (1918) describes the phenomenon of 'air blasts' (rockbursts) in the Kolar Gold Field and refers to similar problems in the Hillgrove area of New South Wales, the Witwatersrand mines in South Africa and mines in the Czech Republic.

Interest in the relationship between stress, rock strength and rock mass damage, is universal in the mining geomechanics community, and is the subject of innumerable publications; only a few of the key references are discussed briefly here.

Hoek and Brown (1980) discuss the observed ground behaviour in mines in the Zambian Copperbelt and the Witwatersrand gold mines in South Africa and related this to the ratio between the applied stress and laboratory strength, $\sigma_{\mathrm{c}}$. The mining geology in these two districts is dominated by quartz-rich, massive, and very strong rocks. Not surprisingly, the rock mass response to elevated stresses involves brittle, often violent failure mechanisms such as spalling and rockbursts.

Hoek and Brown's concept was further developed by Martin et al. (1999), based in part on their extensive studies of rock damage and damage mechanisms at the Underground Research Laboratory in Canada.

They presented a matrix illustrating the progression of increasing damage associated with increasing stress to strength ratio, and decreasing rock mass quality in terms of the geological strength index. This was updated by Kaiser et al. (2000) and includes a comparison of the mining-induced stress and rock strength (right hand column, Figure 1).

This concept has been further developed by Vakili et al. (2013), including the introduction of closure strain values for each of the categories as shown in Figure 2.

Similarly, squeezing ground behaviour has challenged tunnelling and mining operations in weak rock masses from the earliest stages of modern mining history. The Blackwater mine in New Zealand is an example of a so-called 'hard rock' mine that experienced severe squeezing behaviour during the 1940s (Pearson 1942).

In Western Australia's Yilgarn mining district and Canada's Sudbury region, so-called 'hard rock' mining can be somewhat of a misnomer because the geology of many of the gold and nickel mines in these areas include very weak rock materials, in particular serpentinites (talc-chlorite schists) and mica-rich metasediments. These are often strongly foliated, a characteristic that profoundly affects ground behaviour (Sandy et al. 2010). Strength anisotropy is usually highly developed in such rocks.

Compounding the problem, many of the mines in the Yilgarn craton have encountered unusually high horizontal stresses at shallow depth; strain bursting in strong rocks and squeezing in weaker rocks has been observed at depths of $300 \mathrm{~m}$ below surface.

Some of these issues have been discussed previously in the literature, including Sandy and Player (1999), Carr et al. (1999), Struthers et al. (2000), Beck and Sandy (2003), and Sandy et al. (2010).

Canadian experience with squeezing ground is also well-described in the literature, including Sandy et al. (2007), Mercier-Langevin and Turcotte (2007), Mercier-Langevin and Hadjigeorgiou (2011), Hadjigeorgiou et al. (2013) and Mercier-Langevin and Wilson (2013). 


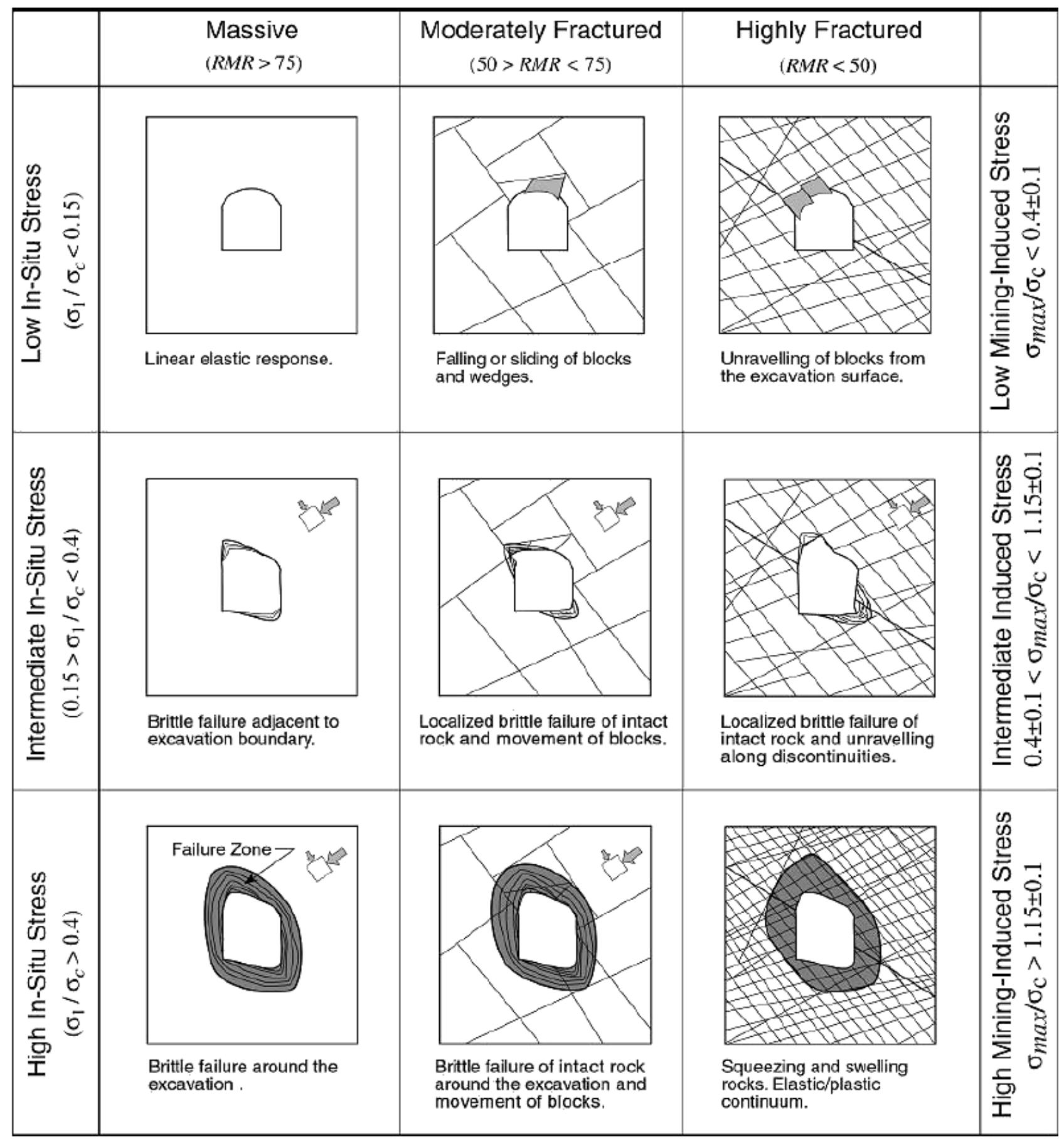

Figure 1 Relationship between damage, increasing stress and decreasing rock mass quality (Kaiser et al. 2000) 


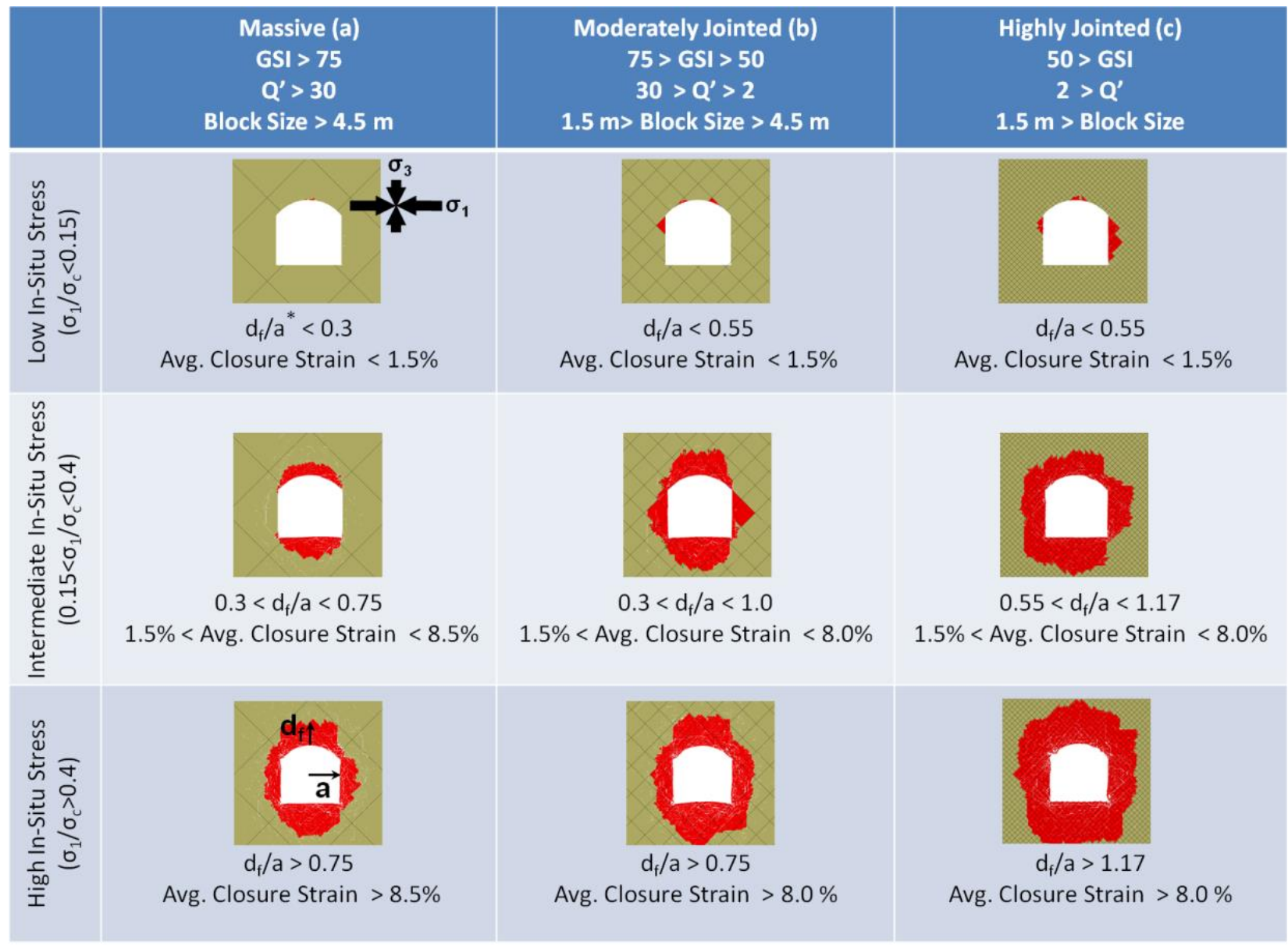

${ }^{*} \mathrm{~d}_{\mathrm{f}} / \mathrm{a}=$ Depth of damage/Radius of opening

Figure 2 Updated matrix of stress versus strength and rock mass quality including reference to closure strains (Vakili et al. 2013)

\section{Ground control in rockburst-prone mines}

The case study presented here refers to a long-hole open-stoping with paste backfill operation in Australia with in situ stresses of up to $72 \mathrm{MPa}$ (major principal stress). Rock strength to rock stress ratios vary from 1.7 to 2.9 in the deepest parts of the mine. The rock mass response to mining in these conditions involves high levels of seismicity leading to progressive rock mass damage and discrete rockburst events. The ground control methods rely on seismic monitoring, the application of various levels of ground support, and careful mine sequencing.

The health of the seismic system is checked on a daily basis and issues are raised immediately in the pre-shift meeting. Daily analysis of seismic data is conducted to check the database for large events $\left(>M_{L} 0\right)$ and to ensure that these have been processed properly. Rock noise reports are investigated to relate with seismicity recorded by the system. Displacement monitoring of stope hanging walls is also conducted using extensometers.

Each development plan is analysed for seismic risk and expected damage. The appropriate ground support scheme is assigned based on this analysis. Face support is recommended for headings that are perpendicular to the major principal stress orientation. Large-scale structures are reviewed for each development plan to ensure that these do not coincide with the placement of large spans (intersections).

Each stope is analysed for seismic risk, placement of brows, requirements for backfill, and requirements for ground support rehabilitation prior to the commencement of stoping activities. Large-scale structures identified from mapping and/or cavity monitoring system (CMS) surveys are checked to determine the risk 
of wedge failure from the hanging wall. Each stope firing is analysed for re-entry times based on the seismic decay of previous blasts with similar characteristics.

Regular geotechnical inspections are conducted for each active development heading, stope brow, and previously identified hazards, such as areas requiring rehabilitation that is not yet completed. Photographs are maintained in a central filing system as records of areas of geotechnical interest. These can be used to monitor changes in ground conditions. Damage mapping is conducted at a minimum of six-monthly basis.

Elasto-plastic numerical modelling is conducted, typically annually as part of the medium and long term planning process. Stoping-related stress changes are back-analysed with the model, which has been calibrated using seismic data and damage mapping. The modelling results are used to determine the appropriate stoping sequence and infrastructure stand-off distances.

Reconciliations are conducted for all completed stopes. The performance of the stope walls is reviewed in terms of overbreak, particularly the hanging wall and footwall. The CMS data is used for the analysis together with structural information and seismic data. Good correlation has been achieved with modelled zones of yield closely agreeing with overbreak/fall-off.

Ground support systems are selected using the largest expected event as indicated by the seismic data to determine the most appropriate selection of ground support elements. The optimal system is designed to provide early confinement but then contain rockburst events if required. The system is expected to limit the amount of rehabilitation required with the ongoing deformation. In the deepest parts of the mine, combinations of fibrecrete, weld mesh, split sets, Normet D-bolts, and twin-strand bulbed cable bolts are used in different patterns for areas expecting various levels of deformation. Osro straps are used on pillars where required. Ground support in the deepest parts of the mine is installed floor to floor, with the section below grade line supported in a separate phase, 20 to $50 \mathrm{~m}$ behind the advancing face.

Quality control of support elements is conducted on a routine basis. This includes pull tests, fibrecrete and grout cylinder tests, fibrecrete round determinate panel tests, and inspections of installation practice. The acceptance criteria for quality control are presented in Table 1. Failures are investigated and the ground support is replaced, if the problem is widespread.

Table 1 Acceptance criteria for ground support quality control

\begin{tabular}{ll|}
\hline Ground support type & Acceptance criteria \\
\hline $2.4 \mathrm{~m}$ split sets - pull test & $10 \mathrm{t}$ \\
\hline $2.4 \mathrm{~m}$ Posimix bolt - pull test & $13 \mathrm{t}$ \\
\hline $2.4 \mathrm{~m}$ D-bolt & $14 \mathrm{t}$ \\
\hline Fibrecrete - cylinder strength & $32 \mathrm{MPa}$ at 28 days \\
\hline Fibrecrete - round determinate panel & $400 \mathrm{~J}$ \\
\hline Cable bolt grout - cylinder strength & $35 \mathrm{MPa}$ at 28 days \\
\hline
\end{tabular}

\section{$4 \quad$ Ground control in hard rock mines with squeezing ground}

The case study presented for squeezing ground conditions refers to another long-hole open-stoping operation with paste backfill in Australia with in situ stresses of up to $62 \mathrm{MPa}$ (major principal stress). Rock strength to rock stress ratios vary from 1.2 to 2.6 at the greatest depth of the mine. Various levels of squeezing ground up to a category of 'severe' squeezing is experienced at this operation ( $>25 \%$ drive closure, as per the scheme proposed by Sandy et al. 2010), with minor seismicity and few damaging seismic events. The ground control methods are focussed around reducing rehabilitation, ground support upgrades and the application of sophisticated numerical modelling methods to determine mine sequencing and mine design. 
Each development plan is assessed for expected levels of deformation based on prior experience in other areas of the mine and appropriate ground support standards are assigned. For example, in development that is assessed as likely to experience severe squeezing, the support standard includes floor to floor fibrecrete, weld mesh to $1.5 \mathrm{~m}$ from the floor, high-displacement bolts (hybrid) in the backs and upper walls spaced at $1.1 \mathrm{~m} \times 1.4 \mathrm{~m}$, and higher-capacity modified split sets (Fero's Highload Spirol Friction Bolt) in the lower walls. The Spirol bolts are installed to avoid damage to loader tyres.

Large-scale structures are reviewed for each development plan to ensure that these do not coincide with the placement of large spans (intersections). Each stope is analysed for expected stand-up time, placement of brows, and requirements for backfill, and requirements for ground support rehabilitation prior to the commencement of stoping activities. CMS data of adjacent stopes is used for each analysis to determine whether overbreak in those stopes could affect planned stoping.

Seismic monitoring is conducted at the mine, however the focus of monitoring is routine inspections, damage mapping and closure monitoring. Routine inspections are conducted generally daily by site geotechnical engineers. The observations are documented and rehabilitation plans are issued immediately. Photographs are maintained in a central filing system as records of areas of geotechnical interest, which can be used to monitor changes in ground conditions. Damage mapping is conducted each time conditions change in the development using a damage scale tailored to suit the mine's typical conditions. The monitoring results are used to calibrate the elasto-plastic numerical model.

Ground support systems are modelled using the Rocscience software Phase2. Trials are conducted to determine the most appropriate selection of elements to contain large deformations for as long as possible. The optimal system is designed to provide early confinement but then deform with the rock mass over time. The system is not expected to stop deformation in squeezing ground (Potvin \& Hadjigeorgiou 2008) but is expected to limit the amount of rehabilitation required. Combinations of fibrecrete, weld mesh, split sets, Spirol bolts, hybrid bolts, twin-strand bulbed cable bolts, and Osro straps are used in different patterns for areas expecting various levels of deformation. In areas where mesh without fibrecrete was applied, the depth of failure was observed to be greater during rehabilitation.

Quality control of the ground support elements is conducted regularly, including pull tests, paste fill, fibrecrete and grout cylinder tests, fibrecrete round determinate panel tests, and inspections of installation practice. The acceptance criteria for quality control are presented in Table 2. Failures are investigated and the ground support is replaced, if the problem is widespread.

Table 2 Acceptance criteria for ground support quality control

\begin{tabular}{ll|}
\hline Ground support type & Acceptance criteria \\
\hline $2.4 \mathrm{~m}$ split sets - pull test & $90 \%$ passing $80 \mathrm{kN}$ \\
\hline Fibrecrete - cylinder strength & $32 \mathrm{MPa}$ at 28 days \\
\hline Fibrecrete - round determinate panel & $360 \mathrm{~J}$ \\
\hline Cable bolt grout - cylinder strength & $50 \mathrm{MPa}$ at 7 days \\
\hline
\end{tabular}

\section{$5 \quad$ Current practices for ground support}

Mines experiencing stress-driven failure such as spalling, rockburst, and squeezing ground require careful consideration of the implications in order to select appropriate ground support for development. These types of rock mass responses present a challenge for maintaining safe access during development and subsequent stoping.

Appropriate surface support needs to be combined with bolts that can withstand often large displacements. Figures 3 and 4 show examples from different mines of intense sidewall buckling where the rock mass bulking locally exceeds $30 \%$. 


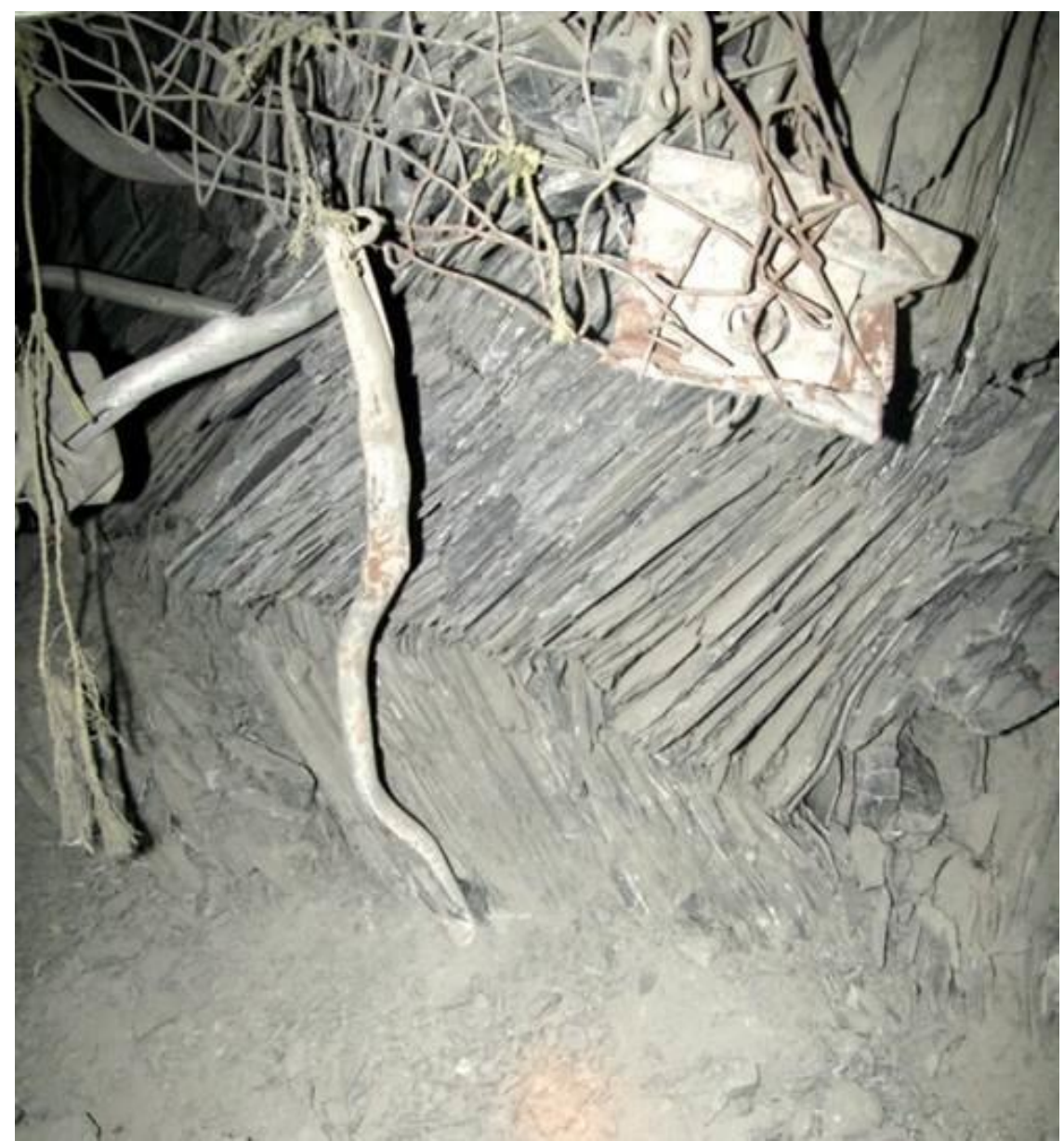

Figure 3 Buckling in the walls with considerable bulking

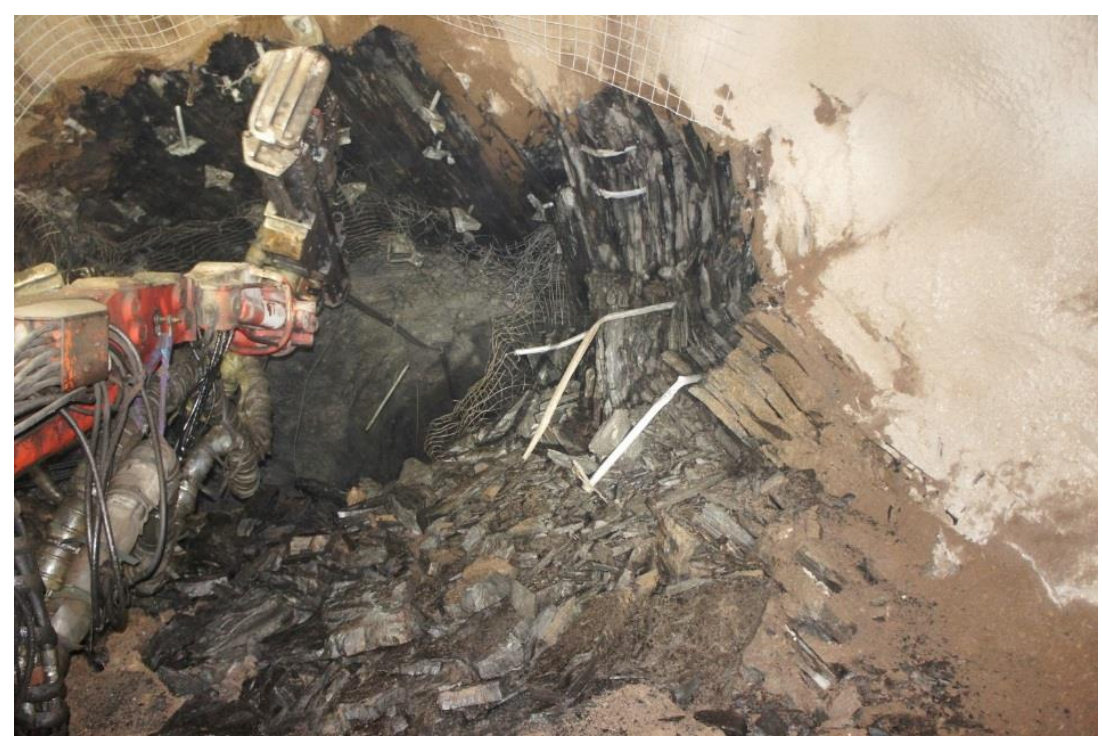

Figure 4 Wall buckling observed during rehabilitation activities 
The rock mass bulking (locally of the order 25 to 35\%) and associated shearing on fractures presents a challenge for most types of ground support, particularly bolts with thin tube construction such as 'Swellex' and 'split set' type bolts.

Numerous, careful observations from more than 20 mines globally show that the bulking and deformation is accompanied by significant shearing. As noted by Beck and Sandy (2003) and Sandy et al. (2010), this can lead to the bolts becoming trapped, and eventually being 'guillotined'. Often the collar fixtures are torn off, rendering the bolt completely ineffective as well as allowing the surface support to 'open up', potentially releasing any contained slabs (Sandy et al. 2007) (Figure 5).

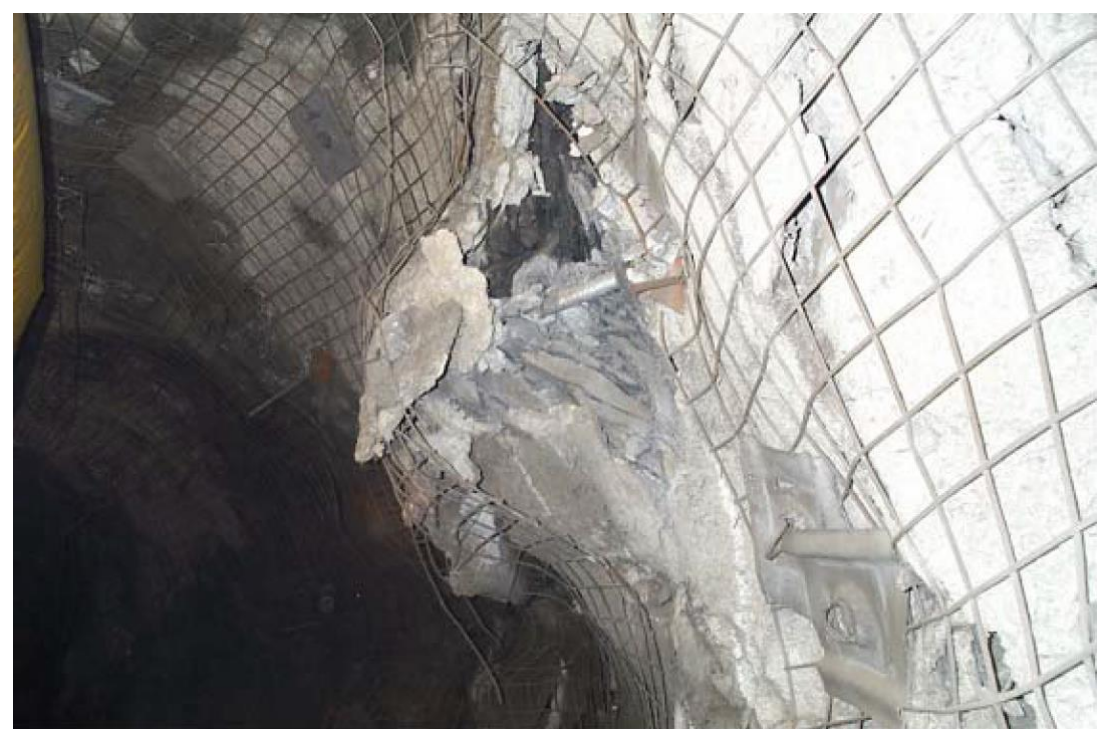

Figure 5 Failure of bolts (split sets) to secure the overlap between adjoining sheets

The combination of fibrecrete and weld mesh is important for controlling ongoing deformation that can occur with stress-driven failure (Louchnikov et al. 2014). The fibrecrete adds early confinement to the rock mass and controls excessive failure from occurring at the active face. The mesh prevents the fibrecrete from becoming a hazard when cracking exceeds the capacity of the fibres.

Development trending perpendicular to $\sigma_{1}$ in high stress mining environments should have some level of dynamic support (Sandy et al. 2010). For mines that are rockburst-prone, the face should be meshed for all development trending perpendicular to $\sigma_{1}$.

Dynamic ground support will be required for areas with a high seismic risk. Seismic risk can be evaluated on site using software such as Vantage from the Institute of Mine Seismology (IMS 2016) or mXrap (Harris \& Wesseloo 2015) from the Australian Centre for Geomechanics (ACG). The software uses the existing seismic database to assess the probability of seismic hazards in certain areas of the mine. These areas are typically proximal to stoping and are closely related to the advancing mining front, or to large-scale structures that are 'reactivated' as a response to mining.

Villaescusa (2014) suggests that the objective for dynamic support in this type of situation should be rockbolts that allow for moderate displacement (about 100-200 mm), shotcrete and mesh. Published case studies have reported success with dynamic ground support systems. Chinnasane et al. (2012) describe using a combination of friction bolts, 4-gauge wire mesh, $75 \mathrm{~mm}$ shotcrete, modified cone bolts, 0-gauge mesh straps, and cable bolts. Turner and Green (2005) describe the good performance of solid bar bolts with mesh for containing small rockbursts, particularly in comparison to friction bolts.

It should be noted that designing support to manage high seismic risk is a complex task and it is beyond the scope of this paper to describe it in detail. A good introduction to the topic is available in the 'Canadian Rockburst Research Program Handbook' (Mining Research Directorate 1996). Examples of the application of this approach are provided by Scott et al. (2008) and Louchnikov and Sandy (2017). Interested readers 
are also referred to the update on this topic provided by Kaiser and Cai (2013) in their Keynote address to Ground Support 2013.

As part of a review of a proposed depth extension to an existing gold mine in Ghana, a benchmarking study was undertaken of current ground support practices in mines with stress-driven failure. The study involved comparing stress versus strength, consideration of modulus/strength, rock mass response, seismicity, and ground support. Seismicity and squeezing ground conditions are rated semi-quantitatively based on the authors' knowledge of the mines. Ratings used for the semi-quantitative assessment are presented in Table 3.

Table 3 Semi-quantitative ratings of dynamic ground conditions

\begin{tabular}{ll}
\hline Rating & Description \\
\hline $\begin{array}{l}\text { Strong } \\
\text { seismicity }\end{array}$ & $\begin{array}{l}\text { Events with } \mathrm{M}_{\mathrm{L}}>1.0 \text { resulting in significant damage to active mine areas, requires } \\
\text { active management including exclusion zones/periods, dynamic support, careful } \\
\text { extraction sequencing with dedicated access }\end{array}$ \\
\hline $\begin{array}{l}\text { Moderate } \\
\text { seismicity }\end{array}$ & $\begin{array}{l}\text { Events with } \mathrm{M}_{\mathrm{L}}>0.0 \text { resulting in visible damage, requires upgraded support, seismic } \\
\text { monitoring using a suitable (mine-wide) system, and assessment of potential re-design } \\
\text { requirements if situation deteriorates (changes to extraction sequence, access) }\end{array}$ \\
\hline $\begin{array}{l}\text { Minor } \\
\text { seismicity }\end{array}$ & $\begin{array}{l}\text { Events with } \mathrm{M}_{\mathrm{L}}<0.0 \text { resulting in little or no damage. Commission portable monitoring } \\
\text { to assess seismic population, and correlation with blasting, structures, } \\
\text { pillars/abutments or otherwise }\end{array}$ \\
\hline $\begin{array}{l}\text { Severe } \\
\text { squeezing }\end{array}$ & $\begin{array}{l}\text { Drive closure typically }>25 \%, \text { requires one or more phases of major rehabilitation, } \\
\text { 'purging' }\end{array}$ \\
\hline $\begin{array}{l}\text { Moderate } \\
\text { squeezing }\end{array}$ & $\begin{array}{l}\text { Drive closure typically } 10-25 \% \text {, specialist yielding support essential to maintaining } \\
\text { control, mesh required over fibrecrete to control scats }\end{array}$ \\
\hline $\begin{array}{l}\text { Minor } \\
\text { squeezing }\end{array}$ & $\begin{array}{l}\text { Drive closure }<10 \%, \text { conventional support mostly effective (may require some } \\
\text { rehabilitation bolting) }\end{array}$ \\
\hline
\end{tabular}

Data from mines with squeezing ground conditions are presented in Table 4 and data from mines with rockburst-prone ground conditions are presented in Table 5. The strength to stress ratio presented in these tables only considers in situ stresses. In some cases, the mines have adopted poor mining sequences with closure pillars, flat mining fronts, or unusually high mining rates, all of which can adversely affect the mining-induced stresses. 
Table 4 Ground support benchmarking data for rockburst-prone mines

\begin{tabular}{|c|c|c|c|c|c|c|}
\hline $\begin{array}{l}\text { Mine } \\
\text { location }\end{array}$ & $\begin{array}{l}\text { Strength: } \\
\text { stress ratio }\end{array}$ & $\begin{array}{l}\text { Rating } \\
\text { (seismicity) }\end{array}$ & Surface support & Rockbolts & $\begin{array}{l}\text { Bolt spacing } \\
\text { (m) }\end{array}$ & Other support \\
\hline $\begin{array}{l}\text { Australia } \\
\text { (Mine A) }\end{array}$ & $1.2-2.6$ & Moderate & $\begin{array}{l}75 \mathrm{~mm} \text { fibrecrete and weld mesh to } \\
1.8 \mathrm{~m} \text { from floor }\end{array}$ & $2.4 \mathrm{~m} \mathrm{D}$-bolt & $1.0 \times 1.5$ & $\begin{array}{l}\text { Face meshed for drives } \\
\text { sub-parallel to } \sigma_{1}\end{array}$ \\
\hline $\begin{array}{l}\text { Australia } \\
\text { (Mine B) }\end{array}$ & $0.5-1.4$ & Strong & $\begin{array}{l}75 \mathrm{~mm} \text { fibrecrete plus weld mesh to } \\
\text { floor }\end{array}$ & 2.4 m Garford dynamic bolt & $1.2 \times 1.2$ & Face meshed \\
\hline $\begin{array}{l}\text { Australia } \\
\text { (Mine C) }\end{array}$ & $3.3-4.2$ & Strong & Mesh $1.8 \mathrm{~m}$ from floor & 2.4 m Kinloc bolt & $1.1 \times 1.1$ & $\begin{array}{l}\text { Closure pillar mining } \\
\text { sequence }\end{array}$ \\
\hline $\begin{array}{l}\text { Australia } \\
\text { (Mine D) }\end{array}$ & $0.6-1.8$ & Strong & $\begin{array}{l}50-75 \mathrm{~mm} \text { fibrecrete plus weld mesh } \\
\text { to floor }\end{array}$ & $2.4 \mathrm{~m} \mathrm{D}$-bolt & $1.4 \times 1.1$ & $\begin{array}{l}\text { Face meshed, cable bolts } \\
\text { and mesh straps }\end{array}$ \\
\hline $\begin{array}{l}\text { Australia } \\
\text { (Mine E) }\end{array}$ & $2.9-5.8$ & Minor & Weld mesh to $2 \mathrm{~m}$ from floor & $2.4 \mathrm{~m}$ de-bonded resin bolts & $1.3 \times 1.2$ & - \\
\hline $\begin{array}{l}\text { Australia } \\
\text { (Mine F) }\end{array}$ & $1.8-5.3$ & - & $60 \mathrm{~mm}$ fibrecrete plus weld mesh & $2.4 \mathrm{~m}$ Garford dynamic bolts & $1.5 \times 1.4$ & - \\
\hline $\begin{array}{l}\text { Australia } \\
\text { (Mine G) }\end{array}$ & $1.4-1.9$ & Strong & $75 \mathrm{~mm}$ fibrecrete plus mesh to floor & $3 \mathrm{~m}$ de-bonded resin bolts & $1.4 \times 1.5$ & $\begin{array}{l}\text { Face meshing where } \\
\text { required }\end{array}$ \\
\hline
\end{tabular}

Table 5 Ground support benchmarking data for mines with squeezing ground

\begin{tabular}{|c|c|c|c|c|c|c|}
\hline $\begin{array}{l}\text { Mine } \\
\text { location }\end{array}$ & $\begin{array}{l}\text { Strength: } \\
\text { stress ratio }\end{array}$ & $\begin{array}{l}\text { Rating } \\
\text { (squeezing) }\end{array}$ & Surface support & Rockbolts & $\begin{array}{l}\text { Bolt spacing } \\
\text { (m) }\end{array}$ & Other support \\
\hline $\begin{array}{l}\text { Australia } \\
\text { (Mine H) }\end{array}$ & $1.2-2.6$ & Severe & $\begin{array}{l}50 \mathrm{~mm} \text { fibrecrete and weld mesh to } \\
\text { floor }\end{array}$ & $2.4 \mathrm{~m}$ hybrid bolt & $1.1 \times 1.4$ & $\begin{array}{l}\text { Cable bolts } 1.5 \mathrm{~m} \text { spacing } \\
\text { and Osro straps }\end{array}$ \\
\hline $\begin{array}{l}\text { Ghana } \\
\text { (Mine I) }\end{array}$ & $0.5-2.2$ & Severe & Weld mesh & $\begin{array}{l}2.4 \mathrm{~m} \text { friction bolts and } \\
\text { cement-grouted solid bar bolts }\end{array}$ & $\begin{array}{l}1.0-1.2 \times \\
1.0-1.2\end{array}$ & Cable bolts \\
\hline $\begin{array}{l}\text { Canada } \\
\text { (Mine J) }\end{array}$ & $0.5-1.6$ & Severe & Weld mesh to $0.6 \mathrm{~m}$ from floor & $\begin{array}{l}2.3 \mathrm{~m} \text { solid bar resin bolts, } \\
2.0 \mathrm{~m} \text { hybrid bolts }\end{array}$ & $0.9 \times 0.9$ & $\begin{array}{l}\text { Cable bolts } 2 \text { m spacing } \\
\text { and mesh straps }\end{array}$ \\
\hline $\begin{array}{l}\text { New } \\
\text { Zealand } \\
\text { (Mine K) }\end{array}$ & 1.2 & Severe & $\begin{array}{l}50 \mathrm{~mm} \text { fibrecrete and weld mesh to } \\
1.5 \mathrm{~m} \text { from floor }\end{array}$ & $2.4 \mathrm{~m}$ grouted DCS & $1.0 \times 1.0$ & Face bolted and meshed \\
\hline $\begin{array}{l}\text { Canada } \\
\text { (Mine L) }\end{array}$ & $0.9-1.4$ & Severe & Weld mesh to $0.6 \mathrm{~m}$ from floor & $\begin{array}{l}2.0 \mathrm{~m} \text { split sets, } 2.3 \mathrm{~m} \text { solid } \\
\text { bar, } 2.0 \mathrm{~m} \text { hybrid bolts }\end{array}$ & $1.2 \times 1.2$ & Mesh straps \\
\hline $\begin{array}{l}\text { Australia } \\
\text { (Mine M) }\end{array}$ & $0.6-1.8$ & Severe & $\begin{array}{l}50-75 \mathrm{~mm} \text { fibrecrete plus weld mesh } \\
\text { to floor }\end{array}$ & $2.4 \mathrm{~m} \mathrm{D}$-bolt & $1.4 \times 1.1$ & $\begin{array}{l}\text { Cable bolts and mesh } \\
\text { straps }\end{array}$ \\
\hline
\end{tabular}




\section{Conclusion}

Ground control methods in mines with rockburst-prone and squeezing ground conditions have similarities, as discussed in the two case studies. These are:

- Development design and stope design checks are conducted.

- Monitoring is conducted by (typically) daily inspections by a geotechnical engineer.

- Methods of quality control of ground support are similar.

- Ground support regimes are adopted using a combination of support elements including mesh, fibrecrete, bolts with a high displacement capability, Osro straps, and cable bolts.

- Elasto-plastic numerical modelling methods are employed as input to mine design and stope sequencing.

The major difference in ground control between the two mines in the case studies is monitoring methods. Although microseismic monitoring is employed at both mines, the mine with rockburst-prone conditions relies heavily on this monitoring during the daily processes and short-term design. The mine with squeezing ground conditions places a higher emphasis on closure monitoring and damage mapping.

The benchmarking information indicates that mines with high stress to strength ratios tend to employ a combination of fibrecrete and mesh for surface support, and bolts with dynamic capability. Face meshing is common, particularly in mines with rockburst-prone conditions.

\section{References}

Beck, DA \& Sandy, MP 2003, 'Mine sequencing for high recovery in Western Australian mines', Aus/MM Bulletin, vol. May/June, no. 3. Carr, C, Lappalainen, P \& Sandy, MP 1999, 'Developments in ground control at Outokumpu's Forrestania Nickel Mines, Western Australia', in E Villaescusa, A Thompson \& C Windsor (eds), Rock Support and Reinforcement Practice in Mining, Balkema, Rotterdam, pp. 227-283.

Chinnasane, DR, Yao, M, Landry, D \& Paradis-Sokoloski, P 2012, ‘Performance of dynamic support in highly burst-prone ground conditions at Vale's Copper Cliff Mine - a case study', in Y Potvin (ed.), Proceedings of the Sixth International Seminar on Deep and High Stress Mining 2012, Australian Centre for Geomechanics, Perth, pp. 57-69.

Hadjigeorgiou, J, Karampinos, E, Turcott, P \& Mercier-Langevin, F 2013, 'Assessment of the influence of drift orientation on observed levels of squeezing in hard rock mines', in Y Potvin \& B Brady (eds), Proceedings of the Seventh International Symposium on Ground Support in Mining and Underground Construction, Australian Centre for Geomechanics, Perth, pp. 109-118.

Harris, PH \& Wesseloo, J 2015, mXrap software, version 5, Australian Centre for Geomechanics, The University of Western Australia, Perth, Western Australia, www.mxrap.com

Hoek, E \& Brown, ET 1980, Underground Excavations in Rock, Institution of Mining and Metallurgy, London.

IMS 2016, IMS Vantage, software, Institute of Mine Seismology, Hobart, www.imseismology.org/download-vantage

Kaiser, PK \& Cai, M 2013, 'Critical review of design principals for rock support in burst-prone ground - time to rethink!', in Y Potvin \& B Brady (eds), Proceedings of the Seventh International Symposium on Ground Support in Mining and Underground Construction, Australian Centre for Geomechanics, Perth, pp. 3-37.

Kaiser, PK, Diederichs, MS, Martin, CD \& Steiner, W 2000, 'Underground works in hard rock tunnelling and mining', GEOENG 2000 Invited Papers, vol. 1, Technomics Publishing, Pennsylvania, pp 841-926.

Louchnikov, V \& Sandy, MP 2017, 'Selecting an optimal ground support system for rockbursting conditions', in J Wesseloo (ed.), Proceedings of the Eighth International Conference on Deep and High Stress Mining, Australian Centre for Geomechanics, Perth, in press.

Louchnikov, V, Sandy, MP, Watson, O, Orunesu, M \& Eremenko, V 2014, 'An overview of surface rock support for deformable ground conditions', Proceedings of the Twelfth AusIMM Underground Operator's Conference, The Australasian Institute of Mining and Metallurgy, Carlton South, pp. 57-65.

Martin, CD, Kaiser, PK \& McCreath, DR 1999, 'Hoek-Brown parameters for predicting the depth of brittle failure around tunnels', Canadian Geotechnical Journal, vol. 36, no. 1, pp. 136-151.

Mercier-Langevin, F \& Hadjigeorgiou, J 2011, 'Towards a better understanding of squeezing potential in hard rock mines', Mining Technology, vol. 120, pp. 36-44.

Mercier-Langevin, F \& Turcotte, P 2007, 'Evolution of ground support practices at Agnico-Eagle's LaRonde Division - innovative solutions to high-stress yielding ground', Proceedings of the First Canada-US Rock Mechanics Symposium, Vancouver. 
Mercier-Langevin, F \& Wilson, D 2013, 'Lapa Mine - ground control practices in extreme squeezing ground', in Y Potvin \& B Brady (eds), Proceedings of the Seventh International Symposium on Ground Support in Mining and Underground Construction, Australian Centre for Geomechanics, Perth, pp. 119-131.

Mining Research Directorate 1996, Canadian Rockburst Research Program 1990-1995, A Comprehensive Summary of Five Years of Collaborative Research on Rockbursting in Hardrock Mines, CAMIRO Mining Division, Canada, pp. 385.

Moore, ES 1918, 'Air blasts in the Kolar goldfield, India', Proceedings of AIMME, Colorado, September.

Pearson, EW 1942, Thesis on the Blackwater Mine, Waiuta, New Zealand, Dissertation, Diploma of Associateship of Otago School of Mines, University of Otago, Dunedin.

Potvin, Y \& Hadjigeorgiou, J 2008, 'Ground support strategies to control large deformations in mining excavations', The Journal of the Southern African Institute of Mining and Metallurgy, July 2008.

Sandy, MP, Gibson, W \& Gaudreau, D 2007, 'Canadian and Australian ground support practices in high deformation environments', in Y Potvin (ed.), Proceedings of the Fourth International Seminar on Deep and High Stress Mining, Australian Centre for Geomechanics, Perth, pp. 297-311.

Sandy, MP \& Player, JR 1999, 'Reinforcement design investigations at Big Bell', in E Villaescusa, A Thompson \& C Windsor (eds), Rock Support and Reinforcement Practice in Mining, Balkema, Rotterdam, pp. 301-315.

Sandy, MP, Sharrock, G, Albrecht, J \& Vakili, A, 2010, 'Managing the transition from low stress to high stress conditions', in P Hagan \& S Saydam (eds), Proceedings of the Second Australasian Ground Control in Mining Conference, The Australasian Institute of Mining and Metallurgy, Calrton South, pp. 247-253.

Scott, C, Penney, AR \& Fuller, P 2008, 'Competing factors in support selection for the West Zone of the Beaconsfield Gold Mine, Tasmania', Proceedings of Narrow Vein Mining Conference 2008, The Australasian Institute of Mining and Metallurgy, Carlton South, pp. 173-178.

Struthers, MA, Turner, MH, McNabb, K \& Jenkins, PA 2000, 'Rock mechanics design and practice for squeezing ground and high stress conditions at Perseverance Mine', in G Chitombo (ed.), Proceedings of MassMin 2000, The Australasian Institute of Mining and Metallurgy, Carlton South, pp. 755-764.

Turner, M \& Green, T 2005, 'Threadbar bolts in a seismically active, high stress, high yield environment - Otter-Juan Mine, Kambalda', in Y Potvin \& M Hudyma (eds), Proceedings of the Sixth International Symposium on Rockburst and Seismicity in Mines, Australian Centre for Geomechanics, Perth, pp. 67-73.

Vakili, A, Sandy, M, Mathews, M \& Rodda, B 2013, 'Ground support design under highly stressed conditions', in Y Potvin \& B Brady (eds), Proceedings of the Seventh International Symposium on Ground Support in Mining and Underground Construction, Australian Centre for Geomechanics, Perth, pp. 551-564.

Villaescusa, E 2014, Geotechnical Design for Sublevel Open Stoping, CRC Press, Taylor and Francis Group, Florida. 